\title{
PERILAKU ADIKTIF TERHADAP GAME PLAYER UNKNOMWN'S BATTLE GROUNDS (PUBG)
}

\author{
Bunaiya \\ Program Studi Antropologi \\ Fakultas Ilmu Sosial dan Politik Universitas Malikussaleh \\ Aceh-Indonesia \\ Korespondensi: Bunaiya @unimal.ac.id
}

\begin{abstract}
The development of online games cannot be separated from the development of technology today. The enthusiasts are not only teenagers, but also adults. This study seeks to examine why the youth of Lhokseumawe City experience addiction to the PUBG game and the social implications caused by the presence of the game. The focus of the research is teenagers aged 18-21 years in Lhokseumawe City. The results showed that addiction to this game was caused by environmental conditions (friends and available facilities), excessive hobbies, as well as because the content presented in this game could stimulate the players' adrenaline. In another language it can be said that the features provided are very masculine. The most obvious social implication due to the presence of this game is a change in lifestyle that occurs in the neighborhood of Lhokseumawe City youth, one of which is in terms of interaction and communication styles. The accumulation of PUBG game behaviors and habits that have become a new lifestyle has led to a thickening of consumerism
\end{abstract}

AbstrakPerkembangan game online tidak terlepas dari berkembangnya teknologi dewasa ini. Peminatnya bukan saja dari kalangan remaja, namun juga kalangan dewasa. Penelitian ini berusaha mengkaji mengapa remaja Kota Lhokseumawe mengalami kecanduan terhadap game PUBG dan implikasi sosial yang ditimbulkan oleh kehadiran permainan tersebut. Fokus penelitian adalah kalangan remaja berusia 18-21 tahun yang ada di Kota Lhokseumawe. Hasil penelitian menunjukkan bahwa kecanduan terhadap game ini disebabkan oleh kondisi lingkungan (teman dan fasilitas yang tersedia), hobi yang berlebihan, juga karena konten yang disuguhkan dalam permainan ini dapat memacu adrenalin para pemain. Dalam bahasa yang lain bisa disebutkan bahwa fitur yang tersedia sangat maskulin. Implikasi sosial yang paling nyata akibat kehadiran permainan ini adalah perubahan gaya hidup yang terjadi di lingkungan remaja Kota Lhokseumawe, salah satunya dalam hal gaya interaksi dan komunikasi. Akumulasi perilaku dan kebiasaan game PUBG yang menjadi gaya hidup baru berujung pada mengentalnya sikap konsumerisme

Kata Kunci: PUBG, Remaja, Perilaku Adiktif, Gaya Hidup 
Aceh Anthropological Journal, Vol. 3, No. 2, hlm: 178-189, Oktober 2019

\section{A. Pendahuluan}

Perkembangan teknologi sekarang ini sangat pesat. Berbagai kemajuannya dapat kita peroleh dengan mudah, diantaranya melakukan komunikasi antar manusia dengan berbagai alat atau sarana, termasuk dalam hal pemilihan hiburan, semisal game online. Implikasi yang bisa dilihat secara nyata dalam kehidupan sosial sebagai efek dari perkembangan globalisasi salah satunya adalah tergantikannya permainan tradisional oleh permainan moderen. Pada era sekarang ini, banyak anak- anak, khususnya remaja yang mulai meninggalkan permainan tradisional dan lebih memilih permainan modern. Hal tersebut dikarenakan permainan moderen jauh lebih asik dan menyenangkan (Kurniawan, 2017: 98).

Pun demikian dengan Game online, ia juga berkembang pesat akhir-akhir ini, semakin lama, permainannya semakin menyenangkan, mulai dari tampilan, gaya bermain, grafis permainan, resolusi gambar dan lain sebagainya. Tak kalah juga bervarisasinya tipe permainan seperti permainan perang, petualangan, perkelahian dan game online jenis lainnya menjadi nilai tambah ketertarikan untuk mencobanya. Salah satu game online yang digemari saat ini adalah Player Unknown's Battle Grounds (PUBG).

PUBG adalah game yang bergenre perang yang bisa dimainkan oleh seratus orang dengan system pembagian tim. Dalam satu tim, bisa empat orang, tiga orang, dua orang bahkan bisa bermain sendiri atau dalam istilah permainan PUBG disebut solo player. Saat ini, PUBG mennjadi salah satu permainan daring yang sangat digandrungi, tak hanya oleh kalangan remaja dan anak-anak, orang dewasa pun ikut mengambil peran dalam permainan tersebut. PUBG kini menjadi game terbaik dan terfaforit nomor tiga versi playstore saat ini (Wikipedia, 18 September 2019). Bisa saja menjadi nomor satu atau dua apabila game ini semakin membludak penggunanya di masa yang akan datang. Pencipta game ini bernama Brendan Greene, seorang pria yang lahir pada tahun 1956 dan berkebangsan Irlandia.

Saat ini, banyak remaja kota Lhokseumawe yang kecanduan bermain game PBUG. Hal ini bisa kita lihat pada kebiasaan remaja yang keseringan nongkrong atau hangout berkelompok di warung kopi untuk memainkan game ini. Tidak terbatas waktu, baik pagi, siang, atau malam begitu mudah kita temukan para penikmat game 
Aceh Anthropological Journal, Vol. 3, No. 2, hlm: 178-189, Oktober 2019

ini di café-café yang menyediakan fasilitas internet gratis di seputaran kota Lhokseumawe. berdasarkan hal tersebut, penulis merasa tertarik dan perlu mendiskusikan terkait gejala sosial yang terjadi akibat kehadiran game PUBG ini, karena itu ada dua pertanyaan pokok yang ingin dijawab dalam tulisan ini, yaitu: 1) mengapa remaja Lhokseumawe mengalami kecanduan terhadap game PUBG?; dan 2) Bagaimana implikasi sosial budaya sebagai akibat dari kecanduan game PUBG pada remaja Kota Lhokseumawe?

\section{B. Metode Penelitian}

Lokasi penelitian ini dilakukan di Kota Lhokseumawe,tepatnya di warung kopi yang dianggap menjadi base camp permainan PUBG, di antaranya: Warung Adek Kopi yang beralamat di Jalan Medan - Banda Aceh, Cunda dan Warung Abi Kupi yang beralamat di Jalan Medan- Banda Aceh, desa Alue Awe, Muara Dua, Kota Lhokseumawe. Penulis sebenarnya tidak hanya membatasi diri dengan ke dua tempat tersebut dalam melakukan kajian ini, karena penulis juga kerap mewawancara atau menjumpai informan yang menurut penulis adalah pelaku "kebudayaan" tersebut.

Pendekatan yang digunakan dalam penelitian ini adalah pendekatan kualitatif dengan studi kajian Budaya, Penelitian kualitatif dimaksudkan untuk memperoleh gambaran yang mendalam dan komperhensif tentang masalah yang diteliti. Teknik pengumpulan data yang penulis lakukan yaitu obsevasi, wawancara mendalam, dan studi dokumen. Observasi memberikan kesempatan bagi peneliti untuk turut merasakan, melihat, mendengar, bahkan terlibat langsung, sementara dengan teknik wawancara, penulis bisa memahami lebih dalam hal-hal yang tidak bisa dipahami hanya melalui sekedar observasi. Studi dokumen dilakukan untuk mendapatkan data sekunder sebagai pelengkap data primer dengan mengumpulkan data dari dokumen-dokumen yang berkaitan dengan game PUBG dan gamers.

\section{Pembahasan}

\section{Game Online, Gaya Hidup (Life Style) dan Perilaku Adiktif}

Game online adalah jenis permainan yang hanya bisa dimainkan apabila perangkat yang digunakan untuk bermain terkoneksi dengan jaringan internet. 
Biasanya game online memungkinkan satu pemain (player) untuk dapat saling terhubung dengan pemain yang lainnya, saling berkontak, baik itu dalam bentuk permainan (seperti pukul-memukul, kerja-kejaran, dan lain-lain) atau juga bisa saling berkirim pesan. Tentunya hal itu mirip seperti layanan pada sosial media (Temukan pengertian, 2013:01). PUBG adalah salah satu jenis permainan yang berbasis pada jaringan internet dan saat ini digandungi oleh berbagai kawula, terutama kalangan remaja.

Permainan ini mejadi komoditas yang dikonsumsi kalangan remaja dewasa ini. Pola konsumtif yang dilakukan secara berkelanjutan kemudian bisa bertransformasi menjadi bagian dari gaya hidup. Ada kesan ketinggalan zaman bagi remaja yang tidak mengetahui permainan jenis ini. Walaupun tidak terlibat dalam ikut bermain, minimal pengetahuan tentang itu harus dimiliki oleh kaum remaja Lhokseumawe jika tidak ingin dilebel "kurang update" oleh sesamanya. Perbedaan utama antara masa lalu dan masa kini bahwa gaya hidup telah menjadi lebih banyak, beragam, dan di atas segalanya, mengambang bebas, yaitu, gaya hidup tidak lagi eksklusif bagi kelas-kelas khusus atau setidaknya bukan pada tingkatan yang sama. Kemakmuran yang meningkat dan mobilitas sosial telah memungkinkan seluruh sektor masyarakat untuk membeli gaya hidup sesuai dengan seleranya masingmasing (Walker, 2010:185).

PUBG bukan hanya sekedar gaya hidup bagi remaja, ia sudah masuk dalam katagori perilaku adiktif. Ketergantungan atau adiktif dapat dikatakan sebagai keadaan yang membuat kita merasa terikat, bisa jadi karena hal tersebut telah kita biasakan dalam waktu yang cukup lama. Sehingga kita terbawa pada perilaku penyebab adiksi secara beulang-ulang dan tak jarang akan membawa seseorang pada tindakan di luar nalar kesadaran norma demi memenuhi keinginan tersebut. Artinya, sudah timbul semacam kondisi ketergantungan dan menjadi kebutuhan dalam diri. Jadi, apa yang dilakukan seseorang akan terus berlanjut untuk mendapatkan kesenangan di dalamnya sehingga terus-menerus dilakukan (Hot-gps, 2018). Permainan PUBG di kalangan para gamers Kota Lhokseumawe sudah menjadi kebutuhan sehingga mereka tidak lagi terikat dengan waktu dalam melakukannya, dan juga terkadang melampaui norma-norma yang diyakini, 
Aceh Anthropological Journal, Vol. 3, No. 2, hlm: 178-189, Oktober 2019

misalnya ketika kalah dalam permainan, dengan mudahnya para pemain mengungkapkan kata-kata kotor, walau itu di tempat umum (public space).

\section{Budaya Nge-Game Online dan Perilaku Adiktif Remaja Kota Lhokseumawe}

Berbagai macam aktifitas manusia tidak bisa dipisahkan dari teknologi sebagai wujud alat bantu untuk melaksanakan tugas-tugasnya dengan lebih efektif dan efisien. Di era perkembangan teknologi yang sangat pesat seperti yang kita rasakan saat ini, tidaklah heran jika dalam kehidupan sehari-hari manusia selalu berdampingan dengan salah satu alat teknologi yaitu Smartphone. Namun sebelum berbicara mengenai Game Online, tentu saja ada baiknya kita membahas bagaimana permainan tradisional terlebih dahulu, karena permainan tradisional adalah salah satu bagian dari ragam budaya yang tumbuh di Indonesia.

Menurut Balai Pengembangan Pendidikan Luar Sekolah dan Pemuda (BPPLSP) permainan tradisional merupakan hasil penggalian dari budaya sendiri yang didalamnya banyak mengandung nilai-nilai pendidikan karena dalam kegiatan permainannya memberikan rasa senang, gembira, ceria pada anak yang memainkannya. Selain itu permainannya dilakukan secara berkelompok sehingga menimbulkan rasa demokrasi antar teman main dan alat permainan yang digunakan pun relatif sederhana (Poros Bumi, 2018). Jadi tidaklah mengherankan jika permainan tradisional merupakan hal yang tak dapat dipisahkan dari kebudayaan.

Seiring berkembangnya zaman maka kini permainan tradisional sedikit demi sedikit terkikis oleh permainan modern yang canggih dan didukung dengan teknologi yang tinggi, contoh teknologi pendukung permainan modern saat ini adalah Komputer dan Smartphone. Baik remaja atau anak-anak di Indonesia kini sering kita jumpai pada tempat seperti warnet dan kafe untuk memainkan permainan modern. Game online menjadi tren baru yang banyak diminati karena seseorang tidak lagi bermain sendirian, tapi memungkinkan mereka dapat bermain bersama puluhan orang sekaligus dari berbagai lokasi pada jaringan komputer yang berdekatan. Kini pemain game atau yang kerap disebut gamers sudah dapat bermain dengan pemain-pemain lain dari tempat yang berbeda, bahkan antar bangsa dan antar negara. Berbagai game yang tersambung dengan jaringan 
internet (online games) ini ternyata lebih banyak diminati dan mempunyai penggemar luar biasa banyak. Jika kita melihat di tempat-tempat persewaan game, maka kita akan menemukan tempat-tempat yang tidak pernah sepi, siang ataupun malam dari para penggemar game. Bahkan pada jam-jam tertentu terdapat banyak user yang rela mengantri.

Di Lhokseumawe sendiri dulunya remaja hanya juga memainkan permainan tradisional, adapun permainan tradisional yang selalu dimainkan oleh remaja Kota Lhokseumawe diantaranya adalah bermain layangan, petak umpet, dan lain-lain. Namun permainan yang berbasis tradisional sudah sangat jarang dijumpai.

Di era modern ini dengan kemajuan teknologi yang luar biasa telah merubah segalanya. Kondisi ini menyebabkan masuknya budaya-budaya baru dengan nilainilai dan norma-norma baru yang akan memberikan pillihan lebih banyak bagi para remaja dalam bergaul. Terutama di perkotaan, yang notabenya mengalami perkembangan lebih cepat akibat globalisasi.

Mereka seakan dituntut untuk mengikuti tren, jika tidak mau dikatakan kuno atau ketinggalan jaman. Kehadiran Game Online di tengah-tengah laju teknologi telah membawa pengaruh besar terhadap perkembangan pribadi dan adaptasi remaja, bahkan tidak sedikit remaja yang berubah menjadi pecandu game sehingga lupa pada jati diri mereka yang sesungguhnya. Waktu yang semestinya dipergunakan untuk bermain dengan teman sebaya atau belajar, telah disita demi bisa duduk berlama-lama untuk bermain game.

Menurut beberapa informan, game PUBG adalah permainan perang yang bisa dimainkan solo ataupun berkelompok, di mana pemain harus berjuang untuk bertahan hidup selama mungkin di dalam arena. Keacakan memang masih jadi sesuatu yang memainkan peran penting di sini karena pemain bisa berakhir beruntung mendapatkan rangkaian senjata dan equipment esensial ketika terjun pertama kalinya, atau berakhir sial dan tak menemukan apapun membuat pemain tak ubahnya mangsa yang menunggu untuk diterkam.

PUBG memiliki daya tarik tersendiri, jelas dari beragam senjata dan kendaraan yang tersedia di dunianya yang lebih utama. Kemudian adalah fitur aim 
atau sasaran tembak PUBG, grafis, kostum, wilayah, efek animasi, dan game play. Beberapa hal inilah yang kemudian menarik perhatian gamers kota Lhokseumawe untuk memainkan game ini dan hal tersebut juga yang tidak dimiliki pada jenis permainan lainnya, yang kemudian daya tarik tersebut membuat pemain game ini betah dan rentan akan kecanduan bahkan senjata tiruan yang ada di PUBG ada gamers yang mengoleksinya.

Berawal dari hal-hal seperti itulah kecanduan terhadap PUBG terbentuk. Turnamen game ini juga kerap sekali digelar di Kota Lhokseumawe. Dari turnamenturnamen itulah ada yang menjadi awal pengetahuan mereka tentang PUBG. Sehingga tak dapat dipungkiri kecanduan terhadap game ini timbul sendiri pada penggunanya. Kecanduan terhadap game PUBG berlangsung terus menerus dan sulit untuk diakhiri oleh individu bersangkutan, bahkan ketika MUI sudah mengeluarkan fatwa bahwa game ini dilarang untuk dimainkan. Perilaku kecanduan terhadap PUBG disebabkan oleh ketersediaan dan bertambahnya jenis-jenis permainan yang ditawarkan didalamnya sejajar dengan perkembangan teknologi. PUBG merupakan kesenangan dalam bermain karena memberi rasa kepuasan tersendiri, sehingga ada perasaan untuk mengulangi lagi kegiatan yang menyenangkan ketika bermain game tersebut.

Melalui permainan ini, para gamers mendapatkan kesenangan, memperoleh sensasi bahagia, bangga, senang, dan puas. Hal tersebut akan membuat perilaku menjadi ketagihan karena menghasilkan rasa gairah dan kesenangan. Dari perspektif pembelajaran sosial, bagaimanapun, akan dikatakan bahwa perilaku ini menjadi berlebihan karena diperkuat oleh faktor-faktor seperti suasana hati, interaksi sosial, dan keuntungan finansial, dan dipasangkan dengan isyarat seperti teman-teman, stres dan bantuan dari stres, yang menjadi pemicu kecanduan terhadap game PUBG ini.

Faktor-faktor Penyebab Remaja Kota Lhokseumawe Mengalami Kecanduan Terhadap game PUBG

Maraknya sebuah kebiasaan yang kemudian mengakibatkan candu pada remaja terhadap PUBG tentu dipengaruhi oleh beberapa faktor yang melatarbelakanginya. Dalam hal ini, peneliti memperoleh data-data terkait 
bagaimana game PUBG dapat menjadi suatu candu di Kota Lhokseumawe berdasar beberapa hasil wawancara dan sumber referensi maupun literatur sebagai penguat gagasan. Terdapat beberapa faktor penyebab remaja Kota Lhokseumawe mengalami kecanduan terhadap game PUBG, yaitu sebagai berikut:

Pertama, tentu yang menjadi faktor utama yang menyebabkan kecanduan adalah lingkungan. PUBG adalah salah satu game mobile yang tengah digandrungi dari anak-anak hingga dewasa di Indonesia. PUBG bukanlah lagi hal yang tabu di lingkungan remaja khususnya gamers Negara Indonesia. Mau tak mau game ini juga bukanlah hal yang asing di lingkungan remaja Kota Lhokseumawe khususnya bagi para gamers. Mau di lingkukan manapun, kalangan apapun, sudah pasti masyarakat tau atau mengenal game ini. Karena lingkunganlah yang juga menarik perhatian pemula sehingga banyak yang tertarik pada game ini.

Faktor kedua yang menyebabkan remaja Kota Lhokseumawe kecanduan terhadap game ini adalah alam permainan PUBG seringkali menyuguhkan kontenkonten yang memacu adrenalin pemainnya. Selain itu, terdapat tantangan yang senantiasa bertambah di setiap level permainan. Hal ini tentu menjadi daya tarik sekaligus merupakan risiko bagi gamers sejati.

Ketiga, karena hobi. Sejatinya seorang gamer sudah pasti selalu tidak lepas dari game, mau itu offline ataupun online. PUBG adalah game online yang menurut gamers Kota Lhokseumawe merupakan game yang telah mencapai tingkat tinggi dari segi kualitas dibandingkan dengan game online berbasis perang

\section{Implikasi Sosial Budaya Dari Kecanduan Game PUBG Pada Remaja}

Perkembangan ilmu dan teknologi yang semakin canggih pada sebuah permainan tentunya mempengaruhi nilai sosial budaya yang serius, terutama pada permainan tradisional. Dapat kita ketahui bahwa jauh sebelum teknologi berkembang, remaja maupun anak-anak terbiasa menghabiskan waktu luang dengan bermain permainan tradisional, contohnya engrang, petak umpet, kelereng, layang-layang, engklek, kasti, patok lele, dan lain sebagainya. Namun sejak adanya game online banyak remaja yang telah beralih dari permainan tradisional ke game online ini. Bagi remaja yang sudah dibekali dengan pengetahuan internet, 
mengakses game online bukanlah hal yang sulit dilakukan. Begitu dahsyatnya game online mengalihkan perhatian remaja sehingga membawa perubahan terhadap permainan mereka sekarang ini

Gaya interaksi dan komunikasi tersebut tentu akan memberikan pengaruh besar terhadap, penafsiran dan pemaknaan dalam bermain PUBG. Penafsiran dan pemaknaan yang diberikan oleh gamers PUBG berbeda dengan gamers-gamers lainnya. Perubahan perilaku dari gaya berbicara seperti itu mereka dengarkan dari periklanan, youtube, teknologi informasi dan komunikasi lainnya. Maka secara sederhana hal ini dapat dikatakan budaya populer yang dihasilkan dari alat-alat teknologi informasi dan komunikasi yang disiarkan dan ditayangkan untuk mendapatkan ketertarikan terhadap penontonnya. Seperti halnya jika seseorang bermain mengikuti cara bermain dari orang yang mempunyai tingkatan yang tinggi dalam game PUBG agar dapat berkembang maka individu tersebut akan melakukan hal yang sama dengan yang dia ikuti. Ketika seseorang mengikuti pola perilaku dari orang lain agar dapat berkembang dalam bermain game, maka saat itu dia juga mengikuti gaya hidup dari orang yang diikuti, bahkan suatu kelompok juga dapat mempengaruhi seseorang agar mengikuti apa yang dilakukan orang-orang yang ada dalam kelompok. Seperti misalnya dalam hal komunikasi dengan lawan bicara, gaya bicara mereka pasti berbeda dengan gaya bicara biasanya.

Menariknya, tidak sedikit dari kalangan gamers PUBG mengikuti atau mengoleksi barang-barang yang ada di game tersebut. Misalnya kostum, senjata, berbagai item dan lain sebagainya yang kemudian akan mereka bawa saat akan bermain PUBG atau mempromosikannya pada saat di adakan turnamen di suatu tempat. Dan tentunya segala barang tersebut tidak hanya mereka beli sendiri namun mereka mendapatkannya dari hadiah memenangkan sebuah turnamen.

Namun selain mempengaruhi gaya hidup seseorang, gamers PUBG juga terkadang cenderung memiliki perubahan perilaku dalam hal emosi yang tidak stabil yang akan berdampak buruk pada relasinya dengan orang lain yang tidak bermain game sehingga sebagian gamers ini terkadang memiliki sifat anti-sosial. Keseringan bermain dengan squad juga menjadi pemicu kurangnya interaksi sosial dengan orang lain atau bahkan keluarga mereka sendiri karena ketika bermain 
PUBG membutuhkan waktu yang lama sehingga waktu dengan dunia nyata terganggu. Selain itu, ada juga gamers yang terkadang meninggalkan kewajibannya di dunia nyata seperti halnya membantu orang tua dirumah, kuliah atau sekolah, dan bekerja. Ini juga akibat dari banyaknya waktu yang dihabiskan oleh gamers untuk memainkan game PUBG dirumah maupun di luar rumah dapat kita ketahui bahwa implikasi sosial budaya dari kecanduan game PUBG pada remaja Kota Lhokseumawe tidak hanya besifat positif saja, namun juga ada yang bersifat negatif. Dampak negatif dari kecanduan game online yaitu lupa waktu, malas belajar, kurang peduli dengan lingkungan sekitar, sulit mengontrol emosi, berambisi menjadi karakter yang dimainkan, dan sering gagal fokus. Kecanduan terhadap PUBG juga mudah dipengaruhi oleh perasaan, emosional kurang stabil, imajinatif, tenggelam dalam pikiran, mandiri, bereksperimen, dan lebih memilih keputusan sendiri.

\section{Kesimpulan}

PUBG awalnya hadir hanya sebagai sebuah kegemaran atau untuk mengisi waktu luang,namun seiiring berjalannya waktu, PUBG menjadi hal yang menimbulkan sifat adiktif dan ketergantungan. Berdasarkan data yang diperoleh, banyak faktor yang menyebabkan remaja Kota Lhokseumawe mengalami kecanduan memainkan game PUBG, di antaranya adalah permainan PUBG menyuguhkan konten yang memacu adrenalin pemainnya. Selain itu, terdapat tantangan yang senantiasa bertambah di setiap level permainan. Hal ini tentu menjadi daya tarik sekaligus merupakan risiko bagi gamers sejati.

Hobi adalah alas an lainnya mengapa seseorang mencintai PUBG. Sejatinya, seorang gamers sudah pasti selalu tidak lepas dari game, mau itu offline ataupun online. PUBG adalah game online yang menurut gamers Kota Lhokseumawe merupakan game yang telah mencapai tingkat tinggi dari segi kualitas dibandingkan dengan game online berbasis perang Battle Royale lainnya.

Adapun implikasi sosial budaya dari kecanduan game PUBG pada remaja di Kota Lhokseumawe paling tampak tentu pada munculnya ruang sosial baru yang dalam hal ini terwujud lewat lahirnya teman-teman atau kalangan gamers PUBG di Kota Lhokseumawe. Tanpa disadari, mereka telah membentuk suatu pembedaan kelas antara diri mereka dengan orang lain. Nilai prestise, elegansi, dan classy game 
Aceh Anthropological Journal, Vol. 3, No. 2, hlm: 178-189, Oktober 2019

PUBG menjadi salah satu faktor yang menyebabkan terbentuknya kelas-kelas tersebut. Termasuk dalam hal cara berkomunikasi, apa yang mereka dapatkan dalam dunia PUBG terbawa secara tidak sadar dalam dunia nyata. 
Aceh Anthropological Journal, Vol. 3, No. 2, hlm: 178-189, Oktober 2019

\section{Daftar Pustaka}

Housee-gps. 2018." Manusia Perilaku Adiktif". https://www.house ftruthgps.com.Diakses pada 18 Oktober 2019.

Kurniawan, "Pengaruh Instensitas Bermain Game Online Terhadap Prilaku Prokrastinasi Akademik Pada Mahasiswa Bimbingan Dan Konseling Universitas PGRI Yogyakarta", Jurnal Konseling Gusgijang Vol.3 No.1,2017.

Poros Bumi. 2018. "Pengertian Permainan Tradisional”. https://porosbumi.com. Diakses pada 19 September 2019.

Temukan Pengetian. 2019. "pengertian Game Online". https://www.temukanpengertian.com. Diakses pada September 2019

Walker, Jhon A. 2010. Desain, Sejarah, Budaya: sebuah pengantar komprehensif. Yogyakarta: Jalasutra.

Wikipedia. 2019. “Player Unknown's Battle Grounds”.. https://id.wikipedia.com. Diakses pada 18 September 2019 